\title{
MODEL OF LOCAL ECONOMIC DEVELOPMENT IN HUNGARIAN COUNTRYSIDE
}

\author{
Brigitta Zsótér ${ }^{1}$, Sándor Illés ${ }^{2}$, Péter Simonyi ${ }^{3}$
}

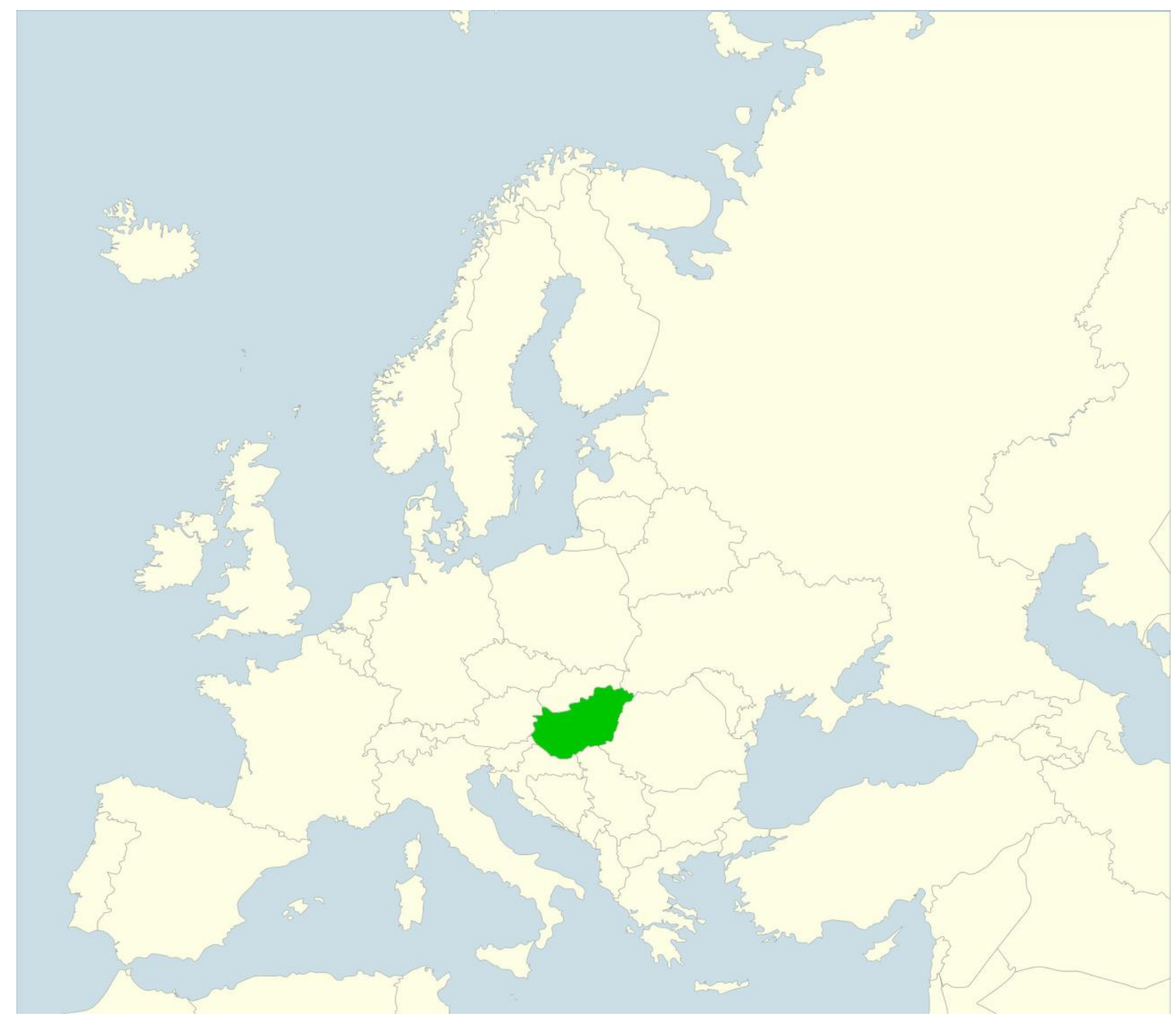

\footnotetext{
1 Associate professor Dr. Habil. Brigitta Zsótér, PhD., University of Szeged, Hungary, email: zsoterb@mk.uszeged.hu

2 Dr. habil. Sándor Illés, PhD., Director, Ageing Ltd., Budapest, Hungary, ORCID: 0000-0001-9436-8719, email: dr.illes.sandor@gmail.com

${ }^{3}$ Dr. Péter Simonyi, Executive director, Active Society Foundation, Budapest, Hungary, email: sapi109@gmail.com
} 
Abstract: During and the following years of economic crisis that started in 2008, the European Union did not find reliable answers to some negative effects of downturn. This was highly true in East Central Europe, in the ex-socialist countries. Regional differences increased at the expanse of rural areas. The inefficient efforts to revitalize rural countryside echoed new. The main aim of the paper is to investigate on the necessary elements and mechanisms of employment growth in Hungarian rural areas. Based on the original applied research series conducted in 2012-2013 and 2015-2016, and the publication of the first results in line with the relevant literature, the authors built a general model inspired by geographical spheres for practical use of stakeholders and policymakers. The parts of the model, the interrelations, mechanisms and functions between them were the subject matter of this paper. The authors expect debate on further generalization of the model.

Keywords: rural development, local economic development, local management, economic geography, model building, economic crisis, Hungary

Absztrakt: Az Európai Unió nem találta meg a megfelelő válaszokat a 2008-tól kibontakozó világgazdasági válság tovagyürűző negatív hatásaira. Ez a megállapítás még inkább érvényes az egykori szocialista országokra Kelet-Közép-Európában, ahol a vidéki térségek rovására növekedtek a regionális különbségek. A vidék felvirágzását célzó intézkedések alacsony hatásfoka, új megoldások keresését tette szükségessé. A tanulmány fö célja az volt, hogy feltárja a foglalkoztatás növelésének alapvető elemeit és mechanizmusait a vidéki Magyarországon. A 2012-2013, 2015-2016 között megvalósított alkalmazott kutatás-sorozat már nyilvánosságra hozott eredményei és a vonatkozó szakirodalom alapján, a szerzők egy általános modellt építettek fel, amelyet a földrajzi szférák inspiráltak és a politikaformálók gyakorlati felhasználására szántak. A modell elemei, kapcsolatai, működési és funkcionális mechanizmusai adták a dolgozat tárgyát. A szerzők tudatában vannak a modell vitatható voltával és várják az észrevételeket a további általánosítás érdekében.

Kulcsszavak: vidékfejlesztés, helyi gazdaságfejlesztés, helyi menedzsment, gazdaságföldrajz, modellépítés, gazdasági válság, Magyarország

\section{Introduction}

Low level of employment remained one of the most serious economic and social problems in Hungary after the last economic crisis. The average rate of employment encompassed enormous territorial differences. The smaller area investigated the bigger spatial inequality appeared. This correlation was the main reason why the spatial level of settlement was chosen in originally in the research series.

The early birth of welfare state described by János Kornai (2000), famous Hungarian economist, is being in death agony in Hungary. According to the opinion of economic geographers, alternative economists, sociologists and spatial developers, the economy as a complex system will not function the same way than before the latest world economic and financial crises (Connolly, 2012; Korompai et al. 2017; Kovách, 2000; Pappalardo et al. 2018). There needs to be a change of the mainstream socio-economic perspective and usual practice in the contemporary society.

The multi-dimensional model fitting for rural settlements less than 20,000 inhabitants were separated by the spheres of sustainability, well-being and security (see Fig. 1). The fulfilment of these three values was the general aim of local management. Local patriotism was situated in the heart of the model. Around local patriotism, three key-points were crystallized: local products, local heroes, and local institutions. The core triads and the inner and outer spheres, 
were stretched by different sort of local politics with their principles. The general model was a quasi-open system. Our ambition is to disseminate, discuss and develop it.

The paper is structured as follows: The next section presents the context of the theories of Local Economic Development (LED). After that, we encompass the published research results erecting from the original project, 'Enhancing local employment'. In the following section, we turned to the model building of LED. This is the main part of the paper. We described the elements of the model, explained mechanisms of the functions. The conclusion and discussion may generate following debates according to the authors' ambitions.

\section{Theoretical background}

The rebirth of the local dimension of economy in the EU happened parallel to the realisation of ineffectiveness of regional based developmental policy (Barca, 2009). The main aim of this paradigm was the development balance of regions and the regional cohesion. However, the growing territorial differential as an inherent consequence of LED was one of the basic immanent features of its own. The appropriate communication of this inevitable effect will be the main task for the actors of LED direction for the politicians, other stakeholders and more general, the public. Only few settlements created and implemented successful local economic diversification strategy. The locally based development involves the appreciation of geographical knowledge in which, localism is the basic concepts ahead of areas, territories and regions (Garcilazo, 2011).

The phenomenon of localism, in other word local patriotism in Hungary has a well-established tradition in international comparison (Csepeli and Örkény, 1999). It contributes on one side the extremely strong force in direction of one settlement and on the other side it involves-low rate of internal mobilities (Bálint, 2012; Kiss et al. 2017; Kiss, 2018). But in the international context, the phenomenon of localism does not restrict only one place, the usual place of residence, (Nadler, 2012; Lampič, and Mrak, 2012) due to the translocal-transnational circular migration of individuals (Illés and Kincses, 2018). The enhancing action space of mobile persons multiplies the realm of local patriotism (Carson and Koch, 2013).

Large variety of local economies contributed to the problems of the universal definition of LED. Scholars have attempted to define the LED generally in many ways so far. Their intentions were foredoomed to failure since the essence of LED lay in the grandeur of uniqueness. As a starting point of our research, we accepted the approach accordingly to which the local economy was the lowest operating level of economy where production and consumption could be connected directly (Mezei, 2006; Walburn, 2011).

The ideas, measures, capital flows came from exogenous sources which resulted in temporary prosperity in the receiving areas during the period of the projects. Contrary to this approach, the developmental sources (economic, social, human) erected from endogenous energies could be utilized by the local stakeholders for permanent upward trend in some Hungarian settlements (Bajmócy, 2011). Based on these arguments, we tried to investigate the inner forces of settlements in the applied/research. On this basis, we were aware of the new rural development paradigm of the European Union (EU) 2014-2020, namely the Community-led Local Development (CLLD), a relatively fresh approach for the endogenous growth during the model building (G. Fekete, 2015).

The authors of this article were not directly or indirectly involved in the practice of implementations of EU regulations in Hungary. Some general aims were similar to our original research, just as fostering the development of good policies. However, our particular aim was to increase the employment through local policies from independent researchers' point of view. So, we concentrated on the LED as a traditional concept (Bingham and Mier, 1993; Rapkay et al. 2013) in this article. We stress that the intention behind the research series was not to assess the practice of EU rural development policy (Pappalardo et al. 2018; Patkós, 2018) in settlements under investigation, but was to identify the key factors of success and failure for employment growth on local level. 


\section{Methodology}

The research series consisted of three different phases. First were the fieldworks. In the second stage, initial generalization happened in the form of the publication of results separated. Finally, model building was made. The places of our fieldwork were villages and small towns, with less than 20,000 inhabitants all over Hungary in 2012-2013 and 2015-2016. We stressed that the sample areas represented the uneven rural countryside in Hungary We chose this settlement size because these were the places where the problems of local development and in strong connection with it - employment proved to be the most serious (Simonyi et al. 2013; Skerratt, 2013). Furthermore, we assumed that the overwhelming effect of party policy on national scale was relatively negligible in these smaller settlements, like Baks, Bazsi, Besence, Fertőd, Köröm, Mátraverebély, Mórahalom, Nagyecsed, Oszkó, Pásztó, Rimóc, Sárkeresztúr and Szarvas. The settlements were characteristically different from one another from economic, social and cultural aspects and were situated in all Hungarian regions. This heterogeneity provided a great opportunity, besides discovering specific peculiarities rooted in their location and history, to draw common conclusions about the thirteen settlements involved in our research (Zsótér and Tóth 2014).

Searching for the potential practices, mechanisms and ideas for enhancing employment in rural countryside we distinguished three sorts of research axes. Firstly, it was the investigation of good practices on local level. Secondly, was the identification of potential ingredients of socalled 'recovery cocktail' mixed by local and regional stakeholders. Thirdly, was an attempt to build a model on local economic development (LED) in order to disseminate and dispute it from practical to theoretical angles. We carried out two array of geographical fieldwork with mixed (multiple) methods, according to the requirements of the holistic approach. (Clarke, 2001; Morgan, 2014). For the sake of comparability, the university students collected quantitative data from the local inhabitants with a standard questionnaire. All in all, they gathered 1241 questionnaires. With the help of in-depth interviews, doctoral fellows and trained researchers asked the local stakeholders and collected some pieces of valuable qualitative information. We supposed that the in-depth interviews made it possible to investigate a sort of practice-based assessment. Till the end of the ground research, 109 qualitative interviews were asked. During the fieldwork, systematic geographical descriptions of the settlements and participant observations of local life were additional methods of information gaining. As a methodological experiment, we carried out focus group analysis in nine localities, namely Baks, Bazsi, Köröm, Mátraverebély, Nagyecsed, Pásztó, Rimóc, Sárkeresztúr and Szarvas.

From methodological point of view, the case study was the relevant representation for studying LED (Panke, 2018). The unique case studies investigating settlements were published first. They investigated the good practices on local level (Handlerné Makkos et al. 2012; Szabó, 2012; Simonyi et al. 2013; Eskulics et al. 2014; Kápolnai et al. 2014; Péter, 2014). In the course of initial synthesis making, we encompassed the results of in-depth interviews of both series of research and we selected potential ingredients of so-called 'recovery cocktail' for local utilization (Simonyi et al. 2013; Rapkay et al. 2013; Illés, 2014). From this stage of the research series, the politicians and other actors of different kind could already have been mixing appropriate measures of local development from these elements taking into consideration the uniqueness of places and spaces. Afterwards, for the model building, we organised a last (but we hope not least) 'Budapest focus group meeting' in 2016. In the capital, we discussed the proto-models of LED presented by one of the authors of this paper from the angle of Hungarian countryside for local development (Illés, 2016). Finally, as a next step of the generalisation, we eliminated the settlement specific peculiarities. At the end of the research, we developed an ontologically spatial model of LED in which we encompassed the facts and ideas provided by the research series in the light of relevant literature (see Fig. 1). 


\section{Results}

We conceptualised the development specific spatial model of local economy as a quasi-open system without strict borderlines. The inner side of the model was distinguished from outside world with the general aims of local management as an analogue of geographical spheres, particularly given the tension between a desire for open system with self-selection on the one hand and a wish to control and manage the borders on the other.

In the core of the model four central concepts crystallized:

-I. Local products

-II. Local heroes

-III. Local institutions

-IV. Local patriotism

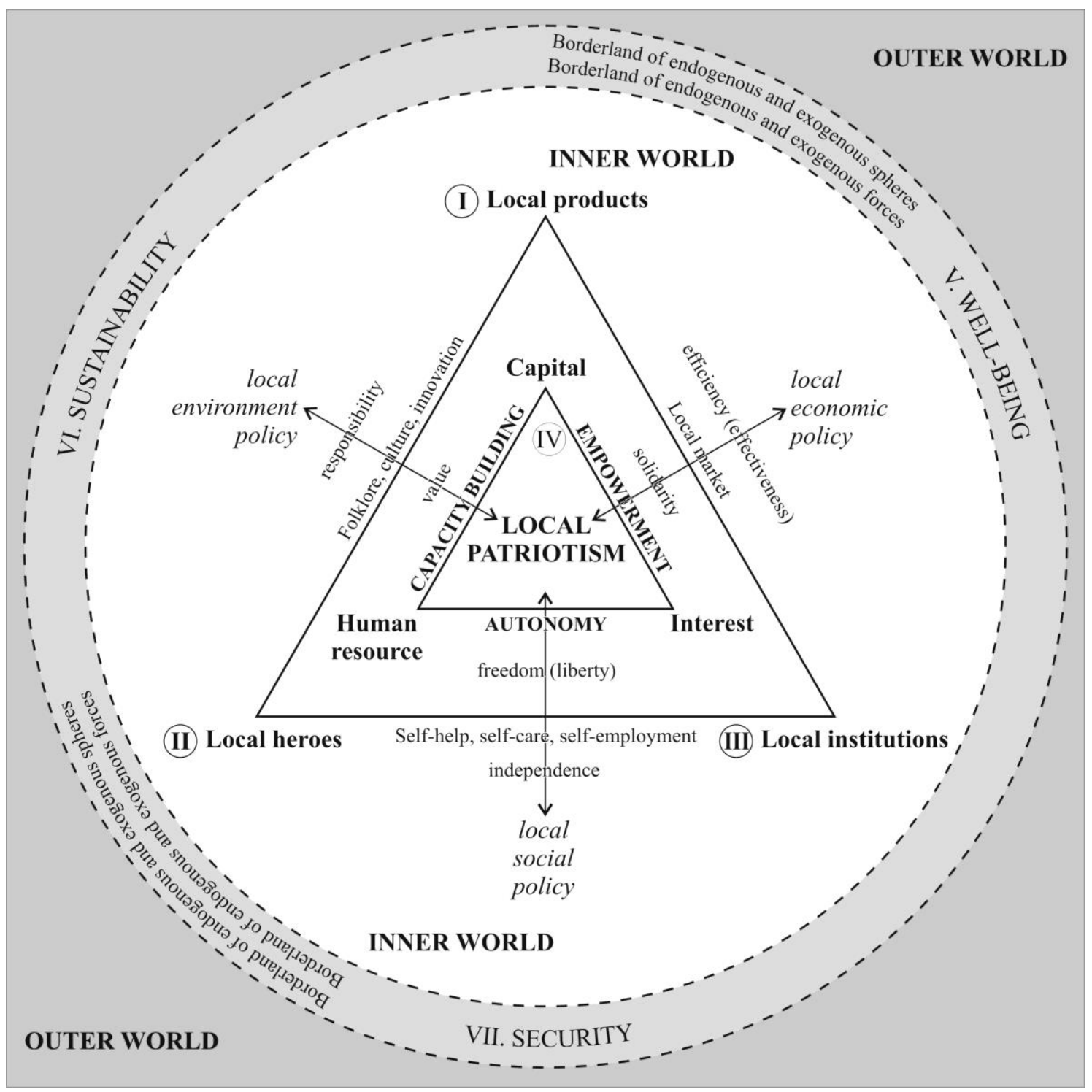

Fig 1. Development specific model of local economy. Source: our elaboration

\subsection{Local products}

The four elements mentioned above provided us the central concern of this development specific model. Local products could be defined as all material and immaterial entities produce the area of concern. However, unique features were not the necessary distinguishing criteria of local products. Uniqueness must have been combined with premium quality, which was realised 
by local persons and foreigners, too. We stressed that local products had material and immaterial attributes (Hribar and Lozej, 2013). According to the case studies, we found more material products than immaterial ones, for instance, coffee machine from Szarvas, fruit syrup from Fertőd, vegetables from Mórahalom, 'gipsy steak' from Nagyecsed and Irsai Grape from Pásztó. The products of rural and health tourism, the local source energy could be conceptualising as local products as well. Without doubt that high quality of local products was in close relationship with small series and hand-made technologies. But unique premium quality local products may emerge as the results of mass-production. In these cases, however, the protection of local label (Pike, 2011) cannot be guarded by local institutions. The power of the state would be inevitable, specifically the struggle against falsifiers.

There has been a mass trend among conscious consumers for local foods purchased directly from farmers in the place where produced and/or at the end of short food supply chain. The relatively close geographic, economic and social relations between producers and consumers have been inevitable requirements of local economic development. The increasing mobility of humans and/or local products has been fuelled by the emerging phenomenon of farmers' market. The volume of so-called farmers' market doubled from the number of 118 in 2012 to 237 in 2016 in Hungary (Szabó, 2017).

We explored less immaterial local products just as legends and myths (Smith et al. 2018). For instance, a myth came from the Eszterházy castle in Fertőd where a ghost room can be found in the desolate part of the building. It was furnished with old fashioned chairs decorated by unusual animal ornaments. One of the members of the fieldwork sensed the spiritual atmosphere in the direct sunlight, too. In another case, the legend of a Saint Woman has been living in the memory of inhabitants in Hasznos, a part of the city Pásztó, where The Blessed Virgin Mary appeared to this local woman as a rare miracle semi-recognised by the Catholic Church.

\subsection{Local heroes}

The so-called local heroes were the key leaders for the extension of employment. They were new sort of actors of paternalism who lived locally or had local connections and who initiated activities, successfully realized projects, co-ordinated different tasks. Recognition of these local heroes and keeping them locally were of basic essence in actions of LED to grow employment. Co-operation between the project-class and local heroes resulted in many successful projects and tenders. „Each initiative is connected to one person, the so-called key figures are extremely significant" said one of the interviewees outlining the above written thoughts in Mórahalom.

If the actors of external intentions for development tried to avoid these local heroes, it should have been expected that there may have been a reduction in efficiency, and the sustainability of the project may have been questioned. Thus, we could put the question why the representatives (sometimes hyenas) of the white-collar project-class with a high level of political commitment would avoid local heroes. For the members of the project-class who would like to keep most part of the development resources for themselves, it was really worth avoiding "these strange locals" who want to select in relation to external resources instead of being happy without hesitation about "the external intention to help" mentioned one of the interviewees with temporary in-migration background in Mátraverebély.

Paternalism had deep roots in the so-called Central-Eastern European region (Szücs, 1988; Kincses et al. 2013). Within the context of the extension of employment of LED, we concluded that the most important factors were the presence of local heroes. They were the new representatives of paternalism, which was relatively independent from the state. It could have been added that although they carried the paternalistic traditions on, they still had an important part in moderation of destroying external effects (state officials, regional bureaucracy, representatives of the project-class). To achieve it, they undertook conflicts even against bureaucracy, which represented the central power.

The mayor, the leader of former agricultural cooperative, the self-employer, the businessman, the tycoon of local ethnic government and the returned local youth as local heroes, worked for 
the enhancemance of the wellbeing of the residents of the settlements. Their own individual profit maximisation was second role. But during the process of decision-making, the local heroes seriously protected their independence and their free will (Illés, 2016; Katonáné Kovács et al. 2016).

It would be a conventional wisdom if we state: local heroes are nothing else than the best quality local stakeholders. However, they not only represent the possibility of an effective decision making process but also create local civic culture. It is clear, that local civic culture changes, although perhaps very slowly (Reese and Rosenfeld, 2001).

\subsection{Local institutions}

The third vertex of the outer equilateral triangle represented is the local institutions (see Fig. 1). It consisted of local governments, non-profit organisations, small and medium size enterprises, banks (most of them have been closed) and as a new institution, the local action groups (LAGs) came originally from EU initiatives. In the thirteen settlements under investigation, the exception of Fertöd, Pásztó and Szarvas, institutions of the local council were the largest and the most stable employers because they performed public services. However, the in-depth interviewees did not see more opportunity of employment in public institutions. It implies that employment, and in some cases, debated over-employment, was state-funded. The determinant feature of state employer clearly strengthened the paternalistic traditions on one hand, and it made local employees vulnerable on the other hand.

The local over-employment will not be sustained after the potential reduction of state redistribution. The necessity of public employment was hardly questioned but its level was considered to be exaggerated and its practice was too diverse. However, at the moment, the interviewees accepted it in the lack of better solutions. "The salary of public workers is enough to survive month by month, but it is not enough for normal life," - mirrored the harsh reality by an interviewee in Köröm.

Just as local heroes, local institutions are not merely victims of globalization and actions of national governments. Local institutions would be the key actors of innovation, mutual learning by doing and the design and implementation of some parts of LED with the balanced mix of formal and informal performances. Efficient local institutional leadership needs to be based on flexibility and forward-looking attitudes. Moreover, the collaboration and power-gaining-sharing plays of other stakeholders wherever possible, are nothing else than the duties of managers (Horlings et al. 2018).

\subsection{Local patriotism}

Local patriotism, a personal form of localism (Hildreth, 2011; Šerý, 2014) was situated in the centre of the inner equilateral triangle (see Fig. 1). It did not simply mean the strong emotional force or admiration of the place. The local patriots served the connection between local production and consumption. According to the authors' personal and disputable opinion, the consumption side of the process must have been stressed because of conscious consumer behaviour (Végh and Illés, 2011), of which the starting point of the LED was closely related with local patriotism.

\subsection{Capital, interest and human resource}

The terrain of local patriotism was stretched by three basic forces: capitals, power to enforce interests and human resources (see Fig. 1). The upper vertex of the inner equilateral triangle meant the ability of the capital formation and capital attraction. The ability to articulate and enforce interests was situated in the right-side vertex just as the ability to create and attract human resources on the left-side. Between capital and interest, the abstract notion of EMPOWERMENT appeared on the straight side. Community empowerment as a whole and empowerment of inhabitants with extra rights and duties were both focused on specifically local politics (Horlings et al. 2018). Between the social space of interest and human resource, we 
realized the second term of AUTONOMY. The multi-faceted autonomy of local inhabitants, institutions, employees and employers were the necessary prerequisites to utilize their specific powers for LED (Hopkin and Atkinson, 2011). CAPACITY BUILDING as the third abstract notion was situated between human resource and capital. The empowerment-autonomy binary of settlements in rural space was often seen to be linked to their capacity buildings. The productional, infrastructural and personal capacities were strong relation with the types of capital - e.g., financial, societal and human (Fischer and McKee 2017). Moreover, the capacity building generated all of the actions and measures of empowered and autonomous local actors. What were the relations amongst three general terms? Without empowerment and capacity building, there was no chance of autonomous local life. Without empowerment and autonomy, the ability of capacity building did would not function. Without autonomy and capacity building, the power of locals served outer interests. We concluded that thick interrelations, in other word, juxtapositions existed amongst three before-mentioned notions.

\subsection{Direction to local politics}

Attila Korompai and his co-authors $(2017,431)$ argued for national level planning and they distinguished four decisive kind of factors on the effective long-term rural development: economic factors, social factors, environmental factors and technological factors. In the concluding section, Korompai et al. $(2017,432)$ hesitated on the local utility of their model: 'as well as the long-term (even extended up to 2050) approach, national rural development planning is necessary and appropriate, but they may also serve as a model for local planning.' We agreed with them to some extent. Their list was expanded by further macro-factors such as cultural and political factors on national and regional level. However, the settlements as the representant of local level inevitably differed from case to case due to their inherent character: uniqueness. It seemed to us that the reduction of factors was the appropriate direction for LED. In the model, we separated three sorts of policy-making on local level: economic, social and environmental.

From the empowerment to the local economic policy, we went through local markets and local retails independent of commercial chains (see Fig. 1). The economic policy was one of the latest but effective parts of the endogenous forces at the borderland of outside world in the model. The local economic policy served two-fold principles. The inner function of economic policy was provided by the common value of solidarity. But turning to the outside world, the function of local economy was to provide the efficiency requirements of the local economic system (Kis et al.2012).

Departing from the autonomy to the local social policy, we moved through the terms: self-help, self-care and self-employment. The local social policy encompassed educational, cultural and territorial mobility features, and it was the second late part of the endogenous spheres with compensatory nature. The local social policy served again two-fold principles. The inner function of social policy was provided by the relative institutional freedom. The freedom was the necessary element of the solidarity. Nevertheless, turned to the outside world, the function of local social policy needed to provide the reproduction of independent employees and employers. Naturally, the local social policies filtered the negative effects of the outside world.

Starting from the capacity building to the local environment policy, we travelled through the notions of folklore, culture and innovation. These were the third late part of the endogenous spheres with the aims of conservations for future generations. The inner function of environment policy was provided by values that were dispersed by education and every day practises on the local economic system. Turning to the outside world, the function of environment policy was to renew the local environment due to the negative consequences of rapidly changing outer ecosystems.

The local economic policy on one hand served the market protection against outer forces, on the other hand, it strengthened the local products with premium quality to reach the outer markets. The local social policy must have stressed the autonomy both inner and outer direction for the reproduction, growth and sustainability of human resources. The local environment 
policy radiated the sustainable development through natural friendly economy with the respect of tradition and principle of innovation production.

The three most future-oriented concepts of the model are as follow: SECURITY (Bingham and Mier, 1993), WELL-BEING (Rablen, 2012; Gébert et al. 2016) and SUSTAINABILITY (McElwee and Whittam, 2012; Zsoter et al. 2014). These spheres can be found in the junction of endogenous and exogenous forces. These target-rational values are the final aims of the LED, namely improving quality of life of inhabitants. For instance, visiting food producers at their home or market places provides security for both sides. On one hand, the final origin of food is well known, on the other hand the direct connection generates secure bargains. Visiting farmers' market for fresh and high-quality foods with better taste than supermarkets contributes to the well-being of individuals involved. The conscious, ethical and social-economic considerations such as visiting local markets, purchasing, local products, protecting local economies for future generations, fosters some parts of inclusive and sustainable development in general (Quendler, 2018). All in all, the most important function of LED is to provide the wellbeing of the locals through managing the change from the point of view of economic geography. But fulfilling the actions for this main purpose the actual security of locals must not damage and the future developmental potential must not diminish.

\section{Conclusion and discussion}

The decline in employment and the rise in unemployment were general consequences of global economic downturn worked in an uneven way from regional perspective. The economic recession caused a larger decline in post-socialist Europe than any other region in the world (Connolly, 2012). Hungary was a small country from the population and territorial angle in Europe with open economy, suffered a deeper and longer falling period in 2008-2011. Devaluation of Hungarian currency, forint (HUF) happened one of the consequences of the crisis (Darvas, 2011). The macro-economic nature of the crisis was similar in the other East and Central European countries: decline in GDP per capita income and growth in unemployment rate. It started as financial crisis that enlarged severe economic and social ones mainly in micro-level due to the predatory lending to private actors (people), just as any part of the world (Illés and Kincses, 2018). With the growth reversal, the credit-fuelled expansion erected from foreign savings ended in inner consumption and investment (Connolly, 2012). Moreover, as a result of the crisis, the sock of private and public debts increased sharply in the edge of crisis in Hungary in 2011. So, the financial crisis escalated into other sectors of the economy, decreased the household real incomes and increased the vulnerability of the whole society. Moreover, the relative regional developmental position of the country worsened in East and Central Europe (Kincses et al. 2013).

After the formal end of Great Recession of twenty-first century, we started our fieldwork. Thirteen places of applied research were Hungarian villages and small towns, with less than 20,000 inhabitants. The settlements investigated were the subjects of local economic development. Municipalities played a key role in stimulating secure and wealthy living conditions for inhabitants, along with sustainable economic-social-cultural life in rural areas. According to two phases of the research (the fieldworks and initial publications), we created a spatial model of local economic development (LED) in order to serve both the local and general employment policies together with economic, social and regional considerations.

We must mention that local action groups (LAGs) functioned as some settlements based on EU regulations. The personnel of this kind of organization was often labelled as the representatives of so-called 'project class' by local inhabitants (Simonyi et al. 2013, 50). In contrast, LAGs were celebrated in the literature as one of the most likely paths of socio-economic rural development (Kovách, 2000). We stressed again that we handled LAGs as one of the research subject matter without any biases. However, the research result, on the evaluation of local action groups (LAGs) financing by EU, for instance, resonated with each other in Hungary and Italy. Csaba Patkós $(2018,103)$ concluded: 'the ability of action groups to co-ordinate local forces and channel them into development programmes through governance is at a low level'. He contextualized his opinion: 'Although Hungarian LAGs, in a European comparison, have many 
levels of tasks, their level of governance is relatively low.' Gioacchino Pappalardo and his coauthors $(2018,560)$ summarized the South Italian situation in relation with the management: 'Within the two examined LAGs, the capacity of adaptive co-management was low. This results negatively affects collective actions and social learning of the LAGs partnership.'.

The questions of local employment had strong relationship with the definitional and modelling problems of LED. In the course of synthesis, we identified the necessary element of successful LED from the angle of Hungarian countryside. Politicians of different kind could mix appropriate measures of LED from these elements taking into consideration the uniqueness of rural places. As a next step of the generalisation, we developed a quasi-general model, which encompassed the facts and ideas provided by the research results. The model focused on pragmatic articulations and-real daily practices. We maintained the dialectical character of model, at first glance, through visualisation: theory-practice, inner world - outer world; spontaneous selection - control-management-governance; core-periphery; present-future. The development specific model of local economy is a quasi-open system, and relatively independent of business cycles and outer economic-social-cultural-political forces. It is built mainly of endogenous factors and inner forces, meanwhile it selects from exogenous developmental potentials (Faragó, 2017). The normative nature is its inherent characteristic. Our approach will strengthen the resilience of settlements and surrounding areas (Simon and Randalls, 2016). As outer forces, we may distinguish nation states and heterogeneous global actors. Nation state forces operate often with centralisation mechanisms. Transnational-supranational-global transformative drivers function often by 'laisser faire' principle (Da Silva Machado, 2017; Horlings et al. 2018). It seems to us that the relevant territorial level of cooperation for rural settlements embed on the build of trans-local connections (Webster, 2017).

Four elements provide the central concern of this development specific model: local products, local heroes, local institutions, and local patriotism. These are circled over items directed to local politics. The inner world of the model has bordered layers filtering from outer world. The final aims and results of LED as abstract notions can be found in the borderland sphere where endogenous and exogenous forces interrelate: well-being, security, sustainability. We hope the model depicted before allows for the exploration and advancement of a unified theory of local economic development in small rural areas (Bingham and Mier, 1993; Bajmócy, 2011).

\section{Acknowledgements}

The research array "Enhancing local employment" was co-financed by Eötvös Loránd University, Together for Future Workplaces Foundation, Active Society Foundation and IX. District Local Government of Budapest. The authors were grateful for the supports.

\section{Academic references}

[1] Bajmócy, Z. (2011). Bevezetés a helyi gazdaságfejlesztésbe. Szeged: JATEPress.

[2] Bálint, L. (2012). Internal migration. In: Öri, P. \& Spéder, Zs., eds., Demographic portrait of Hungary 2012 (pp. 123-134). Budapest: Demographic Research Institute HCSO.

[3] Bingham, R. D. \& Mier, R., eds. (1993). Theories of local economic development. Newbury Park: Sage.

[4] Carson, D. B. \& Koch, A. (2013). Dividing the local: mobility, scale and fragmented development. Local Economy 28(3), 304-319. DOI: 10.1177/0269094212474869.

[5] Clarke, S. E. (2001). Well, maybe: taking context seriously in analysing local economic development. Economic Development Quarterly 15(4), 320-322. DOI: $10.1177 / 089124240101500405$.

[6] Connolly, R. (2012). The determinants of the economic crisis in post-socialist Europe. Europe-Asia Studies 64(1), 35-67. DOI: 10.1080/09668136.2012.635474. 
[7] Csepeli, Gy. \& Örkény, A. (1999). International comparative investigation into the national identity. Review of Sociology 9 (Special Issue), 95-114.

[8] Darvas, Zs. (2011). Exchange rate policy and economic growth after the financial crisis in Central and Eastern Europe. Eurasian Geography and Economics 52(3), 390-408. DOI: $10.2747 / 1539-7216.52 .3 .390$.

[9] Da Silva Machado, F. (2017) Rural change in the context of globalization: examining theoretical issues. Hungarian Geographical Bulletin 66(1), 43-53. DOI: 10.15201/hungeobull.66.1.5.

[10] Eskulics, Gy., Gelencsér, Zs., Horváth, Sz., Siklósi, R. \& Szuromi, O. (2014). Egy hátrányos helyzetü település egyedi lehetőségei és törekvései a helyi gazdaságfejlesztés tekintetében. Jelenkori Társadalmi és Gazdasági Folyamatok 9(1-2), 29-37.

[11] Faragó, L. (2017). Autopoietikus (társadalmi) terek koncepciója. Tér és Társadalom 31(1), 7-29. DOI: 10.17649/TET.30.2.2752.

[12] Fischer, A. \& McKee, A. (2017). A question of capacities? Community resilience and empowerment between assets, abilities and relationships. Journal of Rural Studies 54, 187-197. DOI: 10.1016/j.jrurstud.2017.06.020.

[13] Garcilazo, E. (2011). The evolution of place-based policies and the resurgence of geography in the process of economic development. Local Economy 26(6-7), 459-466. DOI: $10.1177 / 0269094211417363$.

[14] Gébert, J., Bajmócy, Z., Málovics, Gy. \& Pataki, Gy. (2016). Eszközöktöl a jóllétig. A helyi gazdaságfejlesztés körvonalai a képességszemléletben. Tér és Társadalom 30(2), 23-44. DOI: 10.17649/TET.30.2.2752.

[15] G. Fekete, É. (2015). A vidéki munkanélküliség tömegessé válásától az új foglalkoztatási modellekig - Tizenöt év foglalkoztatási tárgyú kutatásai. Budapest: Herman Ottó Intézet.

[16] Handlerné Makkos, D., Ónodi, Zs. \& Schwertner, J. (2012). "Kincs ami nincs" Esettanulmány mint módszer a helyi gazdaság-fejlesztési kezdeményezések értékelésében és tervezésében. Falu Város Régió 19(1-2), 25-31.

[17] Hildreth, P. (2011). What is localism, and what implications do different models have for managing the local economy? Local Economy 26(8), 702-714. DOI: $10.1177 / 0269094211422215$.

[18] Hopkin, D. \& Atkinson, H. (2011). The localism agenda. Local Economy 28(8), 625-626. DOI: $10.1177 / 0269094211422186$.

[19] Horlings, L. G., Roep, D. \& Wellbrock, W. (2018). The role of leadership in place-based development and building institutional arrangements. Local Economy 33(3), 245-268. DOI: $10.1177 / 0269094218763050$.

[20] Hribar, M. Š. \& Lozej, Š. L. (2013). The role of identifying and managing cultural values in rural development. Acta Geographica Slovenica 53(2), 371-378. DOI: 10.3986/AGS53402.

[21] Illés, S. (2016). A helyi gazdaságfejlesztéssel kapcsolatos általánosítási kísérletek. In: Schwarcz, Gy. \& Nagy, N., eds., Önfenntartó falu, fenntartható vidék: Jó gyakorlatok, kreatív megoldások: Helyi gazdaságfejlesztés a Kárpát-medencében (pp. 34-40). Budapest: Nemzetstratégiai Kutatóintézet.

[22] Illés, S. (2014). Local economic development and paternalism in rural Hungary. Paripex Indian Journal of Research 3(2), 122-123.

[23] Illés, S. \& Kincses, Á. (2018). Effects of economic crisis on international circulators to Hungary. Sociology and Anthropology 6(5), 465-477. DOI: 10.13189/sa.2018.060503.

[24] Katonáné Kovács, J., Varga, E. \& Nemes, G. (2016). Understanding the process of social innovation in rural regions: some Hungarian case studies. Studies in Agricultural Economics 118, 22-29. DOI: 10.7896/j.1604. 
[25] Kápolnai, Zs., Takács, K. \& Takács, L. (2014). Helyi gazdaságfejlesztés Bazsi községben. Jelenkori Társadalmi és Gazdasági Folyamatok 9(1-2), 38-46.

[26] Kincses, Á., Nagy, Z. \& Tóth, G. (2013). The spatial structures of Europe. Acta Geographica Slovenica 53(2), 43-70. DOI: 10.3986/AGS53103.

[27] Kis, K., Gál, J. \& Véha, A. (2012). Effectiveness, efficiency and sustainability in local rural development partnerships. Applied Studies in Agribusiness and Commerce 6(3-4), 31-38. DOI: $10.19041 /$ Apstract/2012/3-4/4.

[28] Kiss É., Jankó, F., Mikó, E. \& Bertalan, L. (2017). Bridge and/or springboard: Sopron/Ödenburg, the Hungarian border town's role in internal migration after 1989. Mitteilungen der Österreichischen Geographischen Gesellschaft 159, 199-220. DOI: $10.23781 /$ moegg 159-199.

[29] Kiss, J. P. (2018). Az ingázás mobilitási jellemzői a legutóbbi népszámlálások adatai alapján. Területi Statisztika 58(2), 177-199. DOI: 10.15196/TS580203.

[30] Kornai, J. (2000). What the change of system from socialism to capitalism does and does not mean. Journal of Economic Perspectives 14(1), 27-42. DOI: 10.1257/jep.14.1.27.

[31] Korompai, A., Szabó, M. \& Nováky, E. (2017). Supporting the absorbent national rural development planning by scenarios. European Countryside 9(3), 416-434. DOI: 10.1515/euco-2017-0025.

[32] Kovách, I. (2000). LEADER, as a new social order, and the Central- and East-European countries. Sociologia Ruralis 40(2), 181-189. DOI: 10.1111/1467-9523.00140.

[33] Lampič, B. \& Mrak, I. (2012). Globalization and foreign amenity migrants: the case of foreign home owners in the Pomurska region of Slovenia. European Countryside 4(1), 4556. DOI: 10.2478/v10091-012-0013-8.

[34] McElwee, G. \& Whittam, G. (2012). A sustainable rural? Local Economy 27(2), 91-94. DOI: $10.1177 / 0269094211428865$.

[35] Mezei, C. (2006). A helyi gazdaságfejlesztés fogalmi meghatározása. Tér és Társadalom 20(4), 85-96. DOI: 10.17649/TET.20.4.1079.

[36] Morgan, D. L. (2014). Integrating qualitative and quantitative methods: a pragmatic approach. Los Angeles CA: Sage.

[37] Nadler, R. (2012). Should I stay or should I go? International migrants in the rural town of Zittau/Saxony and their potential impact on regional development. European Countryside 4(1), 57-72. DOI: 10.2478/v10091-012-0014-7.

[38] Panke, D. (2018). Research design and method selection: making good choices in social sciences. Newbury Park: Sage.

[39] Pappalardo, G., Sisto, R. \& Pecorino, B. (2018). Is the partnership governance able to promote endogenous rural development? A preliminary assessment under the adaptive comanagement approach. European Countryside 10(4), 543-565. DOI: 10.2478/euco-20180031.

[40] Patkós, Cs. (2018). Specialities in institutionalisation on Hungarian LEADER local action groups. European Countryside 10(4), 89-106. DOI: 10.2478/euco-2018-006.

[41] Péter, O. (2014). A helyi gazdaságfejlesztés aspektusai Fertőd példáján. Jelenkori Társadalmi és Gazdasági Folyamatok 9(1-2), 47-56.

[42] Péti, M. (2016). A helyi gazdaságfejlesztés megjelenése az Országos Fejlesztési és Területfejlesztési Koncepcióban és a partnerségi megállapodásban. In: Schwarcz, Gy. \& Nagy, N., eds., Önfenntartó falu, fenntartható vidék: jó gyakorlatok, kreatív megoldások: helyi gazdaságfejlesztés a Kárpát-medencében (pp. 49-53). Budapest: Nemzetstratégiai Kutatóintézet. 
[43] Pike, A., ed. (2011). Brands and branding geographies. Cheltenham: Edward Elgar Publishing Ltd.

[44] Quendler, E. (2018). CommunalAudit, a guide for municipalities in Austria to foster inclusive and sustainable development. Studies in Agricultural Economics 120, 17-24. DOI: $10.7896 / \mathrm{j} .1720$.

[45] Rablen, M. D. (2012). The promotion of local wellbeing: a primer for policymakers. Local Economy 27(3), 297-314. DOI: 10.1177/0269094211434488.

[46] Rapkay, B., Illés, S. \& Stárics, R. (2013). A helyi gazdaságfejlesztés egyes gondolati előzményei és következményei. Földrajzi Közlemények 137(1), 28-39.

[47] Reese, L. A. \& Rosenfeld, R. A. (2001). What is the question to which the answer is: local civic culture? Economic Development Quarterly 15(4), 323-326. DOI: $10.1177 / 089124240101500406$.

[48] Šery, M. (2014). The identification of residents with their region and the continuity of sociohistorical development. Moravian Geographical Reports 22(3), 53-64. DOI: 10.2478/mgr2014-0018.

[49] Simon, S. \& Randalls, S. (2016). Geography, ontological politics and the resilient future. Dialogues in Human Geography 6(1), 3-18. DOI: 10.1177/2043820615624047.

[50] Simonyi, P., Illés, S., Zsótér, B. \& Rapkay, B. (2013). Local economic development in the Hungarian countryside: the heritage of paternalism. Central European Regional Policy and Human Geography 3(2), 41-53.

[51] Skerratt, S. (2013). Localism: identifying complexities and ways forward for research and practice. Local Economy 28(3), 237-239. DOI: 10.1177/0269094213485529.

[52] Smith, I. \& Atkinson, R. (2011). Mobility and the smart, green and inclusive Europe. Local Economy 26(6-7), 562-576. DOI: 10.1177/0269094211418899.

[53] Smith, M., Sulyok, J., Jancsik, A., Puczkó, L., Kiss, K., Sziva, I., Papp-Váry, Á. F. \& Michalkó, G. (2018). Nomen est omen - Tourist image of the Balkans. Hungarian Geographical Bulletin 67(2), 173-188. DOI: 10.15201/hungeobull.67.2.5.

[54] Szabó, D. (2017). Determining the target groups of Hungarian short food supply chains based on consumer attitude and socio-demographic factors. Studies in Agricultural Economics 119, 115-122. DOI: 10.7896/j.1705.

[55] Szabó, Sz. (2012). Kiút az elmaradottságból? A Sellyei kistérség esélyei egy fókuszcsoportos interjú tapasztalatai alapján. Comitatus 22(9-10), 55-68.

[56] Szücs, J. (1988). Three historical regions of Europe. In: Keane, J., ed., Civil society and state (pp. 291-332). London: Verso.

[57] Végh, K. \& Illés, S. (2011). Hypothetical models of food consumption behaviour by the elderly. Saarbrücken: Lambert Academic Publishing.

[58] Walburn, D. (2011). Is there a fresh chance for local authorities to take the lead in local economic development? Local Economy 26(2), 75-81. DOI: 10.1177/0269094210397429.

[59] Webster, N. A. (2017). Rural-to-rural translocal practices: Thai women entrepreneurs in the Swedish countryside. Journal of Rural Studies 56, 219-228. DOI: 10.1016/j.jrurstud.2017.09.016.

[60] Zsoter, B., Schmidt, A. \& Trandafir, N. (2014). Research of satisfaction related to investments (2006-2010) accomplished by the local council in Sandorfalva for durable development. Quaestus 3(5), 107-114.

[61] Zsótér, B. \& Tóth, A. (2014). Examination of satisfaction related to investments (20062011) accomplished by the local council in Abony. Analecta Technica Szegedinensia 1(1), 33-37. DOI: 10.14232/analecta.2014.1.33-37. 
[62] Barca, F. (2009). An agenda for a reformed cohesion policy: a place-based approach to meeting European Union challenges and expectations. Independent report prepared at the request of Danuta Hübner, commissioner for regional policy. Available at: http://www.europarl.europa.eu/meetdocs/2009_2014/documents/regi/dv/barca_report_bar ca_report_en.pdf.

[63] Illés, S. \& Simonyi, P. (2016). A helyi gazdaságfejlesztés, településfejlesztés új, a belső eröforrásokra építő módszertanának és új modelljének kidolgozása, a kitörési irányok és a jó gyakorlatok beazonosítása. (Kézirat), Budapest: Aktív Társadalom Alapítvány. 